\title{
РЕКОМБИНАНТНЫЙ ЭРИТРОПОЭТИН И СТАТИНЫ В КОРРЕКЦИИ ЭНДОТОКСИН-ИНДУЦИРОВАННОЙ ЭНДОТЕЛИАЛЬНОЙ ДИСФУНКЦИИ
}

\author{
(C) Денисюк Т.А.
}

\author{
Кафедра фармакологии Курского государственного медицинского университета, Курск \\ E-mail: denitatyana@yandex.ru
}

\begin{abstract}
Механизм кардиопротекторного действия эритропоэтина принципиально отличается от действия статинов, поэтому представляется целесообразным использование сочетанного применения рекомбинантного эритропоэтина «Дарбопоэтин альфа» (500 мкг/кг) с симвастатином, аторвастатином, розувастатином и нанопартикулированным розувастатином на фоне моделирования сепсис-индуцированной патологии, введением штамма 603 Staphylococcus aureus, для проявления эндотелио- и кардиопротективного действия, выражающегося в предотвращении увеличения коэффициента эндотелиальной дисфункции (КЭД), адренореактивности, сохранении миокардиального резерва и нормализации значений биохимических маркеров (Тотал NO, Экспрессия eNOS, C-реактивный белок, ИЛ-6, ФНО). При этом сочетанное применение рекомбинантного эритропоэтина «Дарбопоэтин альфа» (500 мкг/кг) со статинами показало аддитивность эффекта.
\end{abstract}

Ключевые слова: эндотелиальная дисфункция, рекомбинантный эритропоэтин, статины, эндотоксин.

\section{RECOMBINANT ERYTHROPOIETIN AND CORRECTION OF ENDOTOKSIN-INDUCED ENDOTHELIAL DYSFUNCTION BY STATIN Denisyuk T.A.}

Department of Pharmacology of Kursk State Medical University, Kursk

The mechanism of cardioprotective action of erythropoietin is fundamentally different from that of statins, so it seems appropriate to use the combined administration of recombinant erythropoietin "Darbopoietin alpha" (500 mcg / kg) with simvastatin, atorvastatin, rosuvastatin, and nanoparticulate rosuvastatin against the background of modeling sepsis-induced disease through the introduction of 603 Staphylococcus aureus strain in order to detect the endothelio- and cardioprotective effects which manifested itself in preventing the proliferation of endothelial dysfunction coefficient, adrenoreactivity, maintaining myocardial reserve and the normalization of the values of biochemical markers (Total NO, expression of eNOS, C-reactive protein, IL-6, TNF). Thus, the combined application of recombinant erythropoietin "Darbopoietin alpha" (500 mg / kg) with statins revealed the additive effect.

Keywords: endothelial dysfunction, recombinant erythropoietin, statin, endotoxin.

Эндотоксиновый шок с полиорганной патологией $[1,2]$, выброс провоспалительных цитокинов и эндотелиальная дисфункция требуют формирования осознанной стратегии профилактики атеросклеротического процесса [5].

Открытие рекомбинантного эритропоэтина (рЭПО) в миокарде, на мезангиальных клетках, фибробластах мышечной ткани и нейронов позволило изучить неэритропоэтические функции гормона [5]. Кроме того, эритропоэтин (ЭПО) является промоутером эмбриональных стволовых клеток печени, пролиферации эндотелиальных клеток и гладкой мускулатуры [4, 13, 19, 20]. Плеотропные эффекты ЭПО дают перспективы применения его в кардиологии. ЭПО способствует снижению апоптоза эндотелия, редуцированию гипертрофии левого желудочка (ЛЖ), увеличению толерантности к физической нагрузке у больных с хронической сердечной недостаточностью (ХСН) [19].

В связи с этим целью нашего исследования явилось изучение эндотелиопротективной и кардиопротективной активности нового рекомби- нантного эритропоэтина «Дарбопоэтин альфа» в сочетании с ингибиторами ГМГ-Ко-А-редуктазы для коррекции сосудистых осложнений эндотоксиновой интоксикации.

\section{МАТЕРИАЛЫ И МЕТОДЫ ИССЛЕДОВАНИЯ}

Опыты проводились на белых крысах-самцах линии Wistar массой 200-250 г. Моделирование эндотоксин-индуцированной эндотелиальной дисфункции (ЭИЭД) проводили путем подкожного введения 0,1 мл свежей взвеси Staphylococcus aureus (штамм 603) в концентрации 10 миллиардов микробных тел в 1 мл.

Ингибиторы ГМГ-Ко-А-редуктазы в сочетании с рекомбинантным эритропоэтином «Дарбопоэтин альфа» 500 мг/кг вводили ежедневно внутрижелудочно в течение семи суток. Животные были разделены на экспериментальные группы (n = 10): 1 - интактные; 2 - эндотоксининдуцированная эндотелиальная дисфункция (ЭИЭД). 3 - ЭИЭД + «Дарбопоэтин» 500 мг/кг; 
4 - ЭИЭД + симвастатин 8,5 мг/кг; 5 - ЭИЭД + аторвастатин 4,3 мг/кг; 6 - ЭИЭД + розувастатин 8,5 мг/кг; 7 - ЭИЭД + нанопартикулированный розувастатин 11,6 мг/кг; 8 - ЭИЭД + симвастатин 8,5 мг/кг + «Дарбопоэтин альфа» 500 мг/кг; $9-$ ЭИЭД + аторвастатин 4,3 мг/кг + «Дарбопоэтин альфа» 500 мг/кг; 10 - ЭИЭД + розувастатин 8,5 мг/кг + «Дарбопоэтин альфа» 500 мг/кг; 11 ЭИЭД + нанопартикулированный розувастатин 11,6 мг/кг + «Дарбопоэтин альфа» 500 мг/кг.

На 8-й день от начала эксперимента под катетер в левую сонную артерию для регистрации показателей артериального давления (АД), болюсное введение фармакологических агентов осуществляли в бедренную вену. Показатели гемодинамики: систолическое артериальное давление (САД), диастолическое артериальное давление (ДАД) и частоту сердечных сокращений (ЧСС) измеряли непрерывно посредством апмимо измерения АД проводили ряд функциональных проб, проводимых в представленной последовательности: 1. Проба на эндотелийзависимое расслабление сосудов (внутривенное введение раствора ацетилхолина (АХ) в дозе 40 мкг/кг из расчета 0,1 мл на 100 г). 2. Проба на эндотелийнезависимое расслабление сосудов (внутривенное введение раствора нитропруссида натрия (НП) в дозе 30 мкг/кг из расчета 0,1 мл на 100 г) $[6,7,2]$.

Степень эндотелиальной дисфункции у экспериментальных животных, а также степень ее коррекции исследуемыми препаратами оценивали по расчетному коэффициенту эндотелиальной дисфункции (КЭД) $[6,7,2]$. наркозом (хлоралгидрат 300 мг/кг) вводили паратно-программного комплекса "Віорас". По-

Для оценки кардиопротективной активности проводили функциональные пробы на адренореактивность $[6,7,2]$ и исчерпание миокардиального резерва $[6,7,2]$.

Динамику значений биохимических маркеров (Тотал NO, Экспрессия eNOS, C-реактивный белок, ИЛ-6, ФНО) у животных с эндотоксининдуцированной эндотелиальной дисфункцией оценивали с помощью стандартных наборов реактивов [2].

Достоверность изменений абсолютных параметров определяли разностным методом вариационной статистики с нахождением средних значений сдвигов (М), средней арифметической $( \pm \mathrm{m})$ и вероятности возможной ошибки (p) по таблицам Стьюдента. Различия оценивали как достоверные при $\mathrm{p}<0,05$. Статистические расчеты проводились с использованием программы Microsoft Excel 7.0.

\section{РЕЗУЛЬТАТЫ ИССЛЕДОВАНИЯ И ОБСУЖДЕНИЕ}

Монотерапия рекомбинантным эритропоэтином «Дарбопоэтин альфа» (500 мкг/кг) ежедневно внутрижелудочно на фоне моделирования эндотоксин-индуцированной эндотелиальной дисфункции умеренно нормализовала КЭД и существенно не влияла на показатели АД (табл. 1). Значение КЭД составило $1,9 \pm 0,2$ у.е. Ингибиторы ГМГ-Ко-А-редуктазы симвастатин $(8,5$ мг/кг), аторвастатин $(4,3$ мг/кг), розувастатин $(8,5$ мг/кг) и нанопартикулированный розувастатин $(11,6$ мг/кг) в наиболее эффективных дозах существенно улучшали КЭД и не влияли на АД (табл. 1). Значения КЭД находились в диапазоне 2,3-1,5 у.е.

Таблица 1

Влияние применения сочетанной терапии «Дарбопоэтин альфа» с симвастатином, аторвастатином, розувастатином и нанопартикулированным розувастатином на динамику гемодинамических показателей у животных с эндотоксин-идуцированной эндотелиальной дисфункцией (ЭИЭД) $(\mathrm{M} \pm \mathrm{M}, \mathrm{n}=10)$

\begin{tabular}{|l|c|c|c|}
\hline \multicolumn{1}{|c|}{ Группы животных } & САД & ДАД & КЭД \\
\hline Интактные & $129,4 \pm 2,2$ & $89,2 \pm 1,1$ & $1,1 \pm 0,1$ \\
\hline Эндотоксин-идуцированная эндотелиальная дисфункция (ЭИЭД) $(\mathrm{n}=10)$ & $117,6 \pm 2,3^{*}$ & $85,0 \pm 2,1$ & $3,7 \pm 0,5^{*}$ \\
\hline ЭИЭД + «Дарбопоэтин альфа» 500 мкг/кг (n=10) & $126,3 \pm 3,2$ & $83,4 \pm 2,3$ & $1,9 \pm 0,2^{* \#}$ \\
\hline ЭИЭД + Симвастатин 8,5 мг/кг (n=10) & $127,3 \pm 2,8$ & $87,1 \pm 1,9$ & $2,3 \pm 0,5^{* \#}$ \\
\hline ЭИЭД + Аторвастатин 4,3 мг/кг(n=10) & $130,0 \pm 3,3$ & $85,8 \pm 2,2$ & $2,1 \pm 0,3^{* \#}$ \\
\hline ЭИЭД +Розувастатин 8,5 мг/кг (n=1) & $135,0 \pm 3,8$ & $83,1 \pm 2,1$ & $1,7 \pm 0,5^{* \#}$ \\
\hline ЭИЭД + Нанопартикулированный розувастатин 11,6 мг/кг (n =10) & $129,6 \pm 4,3$ & $84,9 \pm 2,0$ & $1,5 \pm 0,2^{* \#}$ \\
\hline ЭИЭД + «Дарбопоэтин альфа» 500 мкг/кг + Симвастатин 8,5 мг/кг (n=10) & $120,1 \pm 3,2$ & $83,1 \pm 2,5$ & $1,6 \pm 0,1^{* \#}$ \\
\hline ЭИЭД + «Дарбопоэтин альфа» 500 мкг/кг + Аторвастатин 4,3 мг/кг $(\mathrm{n}=10)$ & $122,2 \pm 3,3$ & $84,5 \pm 2,7$ & $1,5 \pm 0,1^{* \#}$ \\
\hline ЭИЭД + «Дарбопоэтин альфа» 500 мкг/кг + Розувастатин 8,5 мг/кг (n =1) & $123,1 \pm 2,9$ & $89,0 \pm 2,9$ & $1,6 \pm 0,1^{* \#}$ \\
\hline $\begin{array}{l}\text { ЭИЭД + «Дарбопоэтин альфа» 500 мкг/кг + Нанопартикулированный } \\
\text { розувастатин 11,6 мг/кг (n = 10) }\end{array}$ & $124,3 \pm 3,0$ & $88,4 \pm 2,8$ & $1,5 \pm 0,1^{* \#}$ \\
\hline
\end{tabular}

Примечание: САД - систолическое артериальное давление (мм рт. ст.), ДАД - диастолическое артериальное давление (мм рт. ст.), КЭД - коэффициент эндотелиальной дисфункции (усл. ед.), * - достоверное различие с группой интактных животных $(\mathrm{p}<0,05)$; \# - достоверное различие с группой эндотоксин-идуцированной эндотелиальной дисфункции (ЭИЭД) $(\mathrm{p}<0,05)$. 
Таблица 2

Влияние применения сочетанной терапии «Дарбопоэтином альфа» с симвастатином, аторвастатином, розувастатином и нанопартикулированным розувастатином на динамику показателей сократимости при проведении нагрузочных проб у животных с эндотоксин-идуцированной эндотелиальной дисфункцией

(ЭИЭД) $(\mathrm{M} \pm \mathrm{M}, \mathrm{n}=10)$

\begin{tabular}{|c|c|c|}
\hline Группа животных & $\begin{array}{c}\text { Адрено- } \\
\text { реактивность } \\
\text { (мм рт. ст.) }\end{array}$ & $\begin{array}{c}\text { Исчерпание } \\
\text { миокардиаль- } \\
\text { ного резерва } \\
(\%)\end{array}$ \\
\hline Интактные & $201,5 \pm 9,4$ & $112,7 \pm 10,9$ \\
\hline Эндотоксин-идуцированная эндотелиальная дисфункция (ЭИЭД) (n = 10) & $240,3 \pm 8,7^{*}$ & $79,4 \pm 3,9^{*}$ \\
\hline ЭИЭД «Дарбопоэтин альфа» 500 мкг/кг (n = 10) & $205,7 \pm 7,0^{*}$ & $105,7 \pm 9,5^{*}$ \\
\hline ЭИЭД + Симвастатин 8,5 мг/кг $(\mathrm{n}=10)$ & $232,0 \pm 8,9^{*}$ & $87,4 \pm 3,7^{*}$ \\
\hline ЭИЭД + Аторвастатин 4,3 мг/кг $(\mathrm{n}=10)$ & $222,1 \pm 8,5^{* \#}$ & $97,0 \pm 4,9^{*}$ \\
\hline ЭИЭД + Розувастатин 8,5 мг/кг $(\mathrm{n}=10)$ & $221,0 \pm 8,4^{* \#}$ & $109,4 \pm 5,7^{* \#}$ \\
\hline ЭИЭД + Нанопартикулированный розувастатин 11,6 мг/кг $(\mathrm{n}=10)$ & $219,1 \pm 8,7^{* \#}$ & $99,9 \pm 6,3^{* \#}$ \\
\hline ЭИЭД + «Дарбопоэтин альфа» 500 мкг/кг + Симвастатин 8,5 мг/кг $(\mathrm{n}=10)$ & $201,5 \pm 7,3^{* \#}$ & $101,3 \pm 3,6^{* \#}$ \\
\hline ЭИЭД + «Дарбопоэтин альфа» 500 мкг/кг + Аторвастатин 4,3 мг/кг (n = 10) & $201,5 \pm 6,9^{* \#}$ & $102,1 \pm 3,4^{* \#}$ \\
\hline ЭИЭД + «Дарбопоэтин альфа» 500 мкг/кг +Розувастатин 8,5 мг/кг (n = 1) & $199,3 \pm 7,3^{* \#}$ & $98,9 \pm 4,2^{* \#}$ \\
\hline $\begin{array}{l}\text { ЭИЭД + «Дарбопоэтин альфа» } 500 \text { мкг/кг + Нанопартикулированный } \\
\text { розувастатин } 11,6 \text { мг/кг }(\mathrm{n}=10)\end{array}$ & $197,8 \pm 7,7^{* \#}$ & $105,4 \pm 4,3^{* \#}$ \\
\hline
\end{tabular}

Примечание: * - достоверное различие с группой интактных животных $(p<0,05)$; \# - достоверное различие с группой эндотоксин-идуцированной эндотелиальной дисфункции (ЭИЭД) $(\mathrm{p}<0,05)$.

Сочетанное применение рекомбинантного эритропоэтина «Дарбопоэтин альфа» (500 мкг/кг) со статинами показало аддитивность эффекта в отношении КЭД и АД. Значения оказались даже несколько выше, чем при монотерапии статинами, однако статистически значимо отличались от интактных животных (табл. 1).

Параллельно обнаружена положительная динамика показателей сократимости при проведении нагрузочных проб у животных с эндотоксин-индуцированной эндотелиальной дисфункцией (табл. 2). Рекомбинантный эритропоэтин «Дарбопоэтин альфа» (500 мкг/кг) превосходил статины как в отношении предотвращения увеличения адренореактивности, так и в отношении сохранения расширительного резерва. Сочетанное использование рекомбинантного эритропоэтина «Дарбопоэтин альфа» (500 мкг/кг) с симвастатином, аторвастатином, розувастатином и нанопартикулированным розувастатином привело к аддитивному усилению (табл. 2).

Аналогичная тенденция обнаружена и в отношении значений биохимических маркеров у животных с эндотоксин-индуцированной эндотелиальной дисфункцией (табл. 3).

Наиболее существенно протективное действие сочетанного применения рекомбинантного эритропоэтина «Дарбопоэтин альфа» (500 мкг/кг) с ингибиторами ГМГ-Ко-А-редуктазы симвастатином, аторвастатином, розувастатином и нанопартикулированным розувастатином проявлялось в отношении уровня С-реактивного белка и значений провоспалительных цитокинов ИЛ-6 и ФНО, уровни которых были сопоставимы во всех сериях экспериментов у животных, получавших фармакотерапию. Мы не обнаружили аддитивного действия сочетанного применения на данной модели патологии (табл. 3).

В опытах на сердцах животных (крысах) показано, что применение ЭПО приводит к улучшению коронарной перфузии [17]. Такой эффект вызван активацией эндотелиальной $\mathrm{NO}$ синтетазы и протеинкиназы В, которая активирует фосфорилирование, что приводит к длительной NO-зависимой вазодилатации [18]. Увеличение активных форм АКТ приводит к защите миокарда от ишемии in vivo [17, 18]. AKT (протеинкиназа В) серин-треонин киназа, которая активируется фосфатидилинозитол-3-киназой и играет важную роль в обеспечении жизнедеятельности клетки, блокирует каспазы, функция которых заключается в обеспечении программы апоптоза [18]. Сигнальная система фосфатидилинозитол-3-киназа/АКТ - существует для защиты миокарда от ИП (ишемического прекондиционирования), подобно инсулиновому фактору роста 1 и инсулину [18]. При кислородном голодании ЭПО активирует АКТ (протеинкиназа В) и увеличивает длительность функционирования эндотелиальных клеток и кардиомиоцитов [18]. 
Таблица 3

Влияние применения сочетанной терапии «Дарбопоэтином альфа» с симвастатином, аторвастатином, розувастатином и нанопартикулированным розувастатином на динамику значений биохимических маркеров (Тотал NO, Экспрессия eNOS, C-реактивный белок, ИЛ-6, ФНО) у животных с эндотоксин-идуцированной эндотелиальной дисфункцией (ЭИЭД) $(\mathrm{M} \pm \mathrm{M}, \mathrm{n}=10)$

\begin{tabular}{|c|c|c|c|c|c|}
\hline Группа животных & $\mathrm{NO}_{\mathrm{x}}$ & $\begin{array}{c}\text { Экспрессия } \\
\text { eNOS }\end{array}$ & $\begin{array}{l}\text { Уровень } \\
\text { СРБ }\end{array}$ & ИЛ-6 & $\Phi H O$ \\
\hline Интактные & $116,8 \pm 10,3$ & $5,4 \pm 0,21$ & $0,05 \pm 0,01$ & $0,43 \pm 0,17$ & $8,42 \pm 2,51$ \\
\hline $\begin{array}{l}\text { Эндотоксин-идуцированная } \\
\text { эндотелиальная дисфункция (ЭИЭД) (n=10) }\end{array}$ & $182,3 \pm 12,4^{*}$ & $0,04 \pm 0,01^{*}$ & $0,38 \pm 0,01^{*}$ & $6,87 \pm 1,93^{*}$ & $17,83 \pm 3,79^{*}$ \\
\hline $\begin{array}{l}\text { ЭИЭД + «Дарбопоэтин альфа» } 500 \text { мкг/кг } \\
(\mathrm{n}=10)\end{array}$ & $122,5 \pm 10,5^{* \#}$ & $4,19 \pm 0,72^{* \#}$ & $0,17 \pm 0,01^{* \#}$ & $1,72 \pm 0,97^{* \#}$ & $8,20 \pm 2,26^{* \#}$ \\
\hline ЭИЭД + Симвастатин 8,5 мг/кг $(\mathrm{n}=10)$ & $122,9 \pm 8,4^{* \#}$ & $1,93 \pm 0,12^{* \#}$ & $0,08 \pm 0,01^{* \#}$ & $1,03 \pm 0,62^{* \#}$ & $10,76 \pm 1,70^{* \#}$ \\
\hline ЭИЭД + Аторвастатин 4,3 мг/кг $(\mathrm{n}=10)$ & $130,0 \pm 10,9^{* \#}$ & $2,07 \pm 0,21^{* \#}$ & $0,09 \pm 0,01^{* \#}$ & $1,27 \pm 0,33^{* \#}$ & $9,89 \pm 1,79^{* \#}$ \\
\hline ЭИЭД + Розувастатин 8,5 мг/кг $(\mathrm{n}=1)$ & $122,1 \pm 9,9^{\# *}$ & $3,04 \pm 0,35^{* \#}$ & $0,11 \pm 0,01^{* \#}$ & $1,17 \pm 0,33^{* \#}$ & $10,80 \pm 1,99^{* \#}$ \\
\hline $\begin{array}{l}\text { ЭИЭД + Нанопартикулированный } \\
\text { розувастатин 11,6 мг/кг (n = 10) }\end{array}$ & 132 , & $56^{* \#}$ & $0,01^{* \#}$ & $24^{* \#}$ & $9,56 \pm 1,87^{\text {*\# }}$ \\
\hline $\begin{array}{l}\text { ЭИЭД + «Дарбопоэтин альфа» } 500 \text { мкг/кг + } \\
\text { Симвастатин } 8,5 \text { мг/кг }(\mathrm{n}=10)\end{array}$ & $119,3 \pm 7,7^{* \#}$ & $4,17 \pm 0,47^{* \#}$ & $0,18 \pm 0,12^{* \#}$ & $3,16 \pm 0,26^{* \#}$ & $10,02 \pm 1,18^{* \#}$ \\
\hline $\begin{array}{l}\text { ЭИЭД + «Дарбопоэтин альфа» } 500 \text { мкг/кг + } \\
\text { Аторвастатин 4,3 мг/кг }(\mathrm{n}=10)\end{array}$ & $120,1 \pm 7,6^{* \#}$ & $4,59 \pm 0,49^{* \#}$ & $0,15 \pm 0,11^{* \#}$ & $3,89 \pm 0,17^{* \#}$ & $1,42^{* \#}$ \\
\hline $\begin{array}{l}\text { ЭИЭД + «Дарбопоэтин альфа» } 500 \text { мкг/кг + } \\
\text { Розувастатин } 8,5 \text { мг/кг }(\mathrm{n}=1)\end{array}$ & $119,4 \pm 7,7^{* \#}$ & $4,67 \pm 0,48^{* \#}$ & $0,16 \pm 0,10^{* \#}$ & $4,02 \pm 0,21^{* \#}$ & $10,40 \pm 1,04^{* \#}$ \\
\hline $\begin{array}{l}\text { ЭИЭД + «Дарбопоэтин альфа» } 500 \text { мкг/кг } \\
\text { Нанопартикулированный розувастатин } \\
11,6 \text { мг/кг (n=10) }\end{array}$ & $109,5 \pm 7,3^{* \#}$ & $4,95 \pm 0,53^{* \#}$ & $0.20 \pm 0.11^{* \#}$ & $4,09 \pm 0,24^{* \#}$ & $10,60 \pm 1,50^{* \#}$ \\
\hline
\end{tabular}

Примечание: $\mathrm{NO}_{\mathrm{x}}$ - конечные метаболиты NO (мкмоль/л); экспрессия еNOS (\%); уровень СРБ - С-реактивного белка (мг/л); ИЛ-6 - интерлейкин 6 (пг/мл) ФНО - фактор некроза опухоли (пг/мл), * - достоверное различие с группой интактных животных $(\mathrm{p}<0,05)$; \# - достоверное различие с группой эндотоксин-идуцированной эндотелиальной дисфункции $(Э И Э Д)(p<0,05)$.

Одним из плеотропных эффектов ЭПО и его аналогов является уменьшение апоптоза. C.J. Parsa et al. показали, что предварительная обработка ЭПО миобластов уменьшает перекисный апоптоз на 50\%.

Результаты экспериментов, полученные в нашей лаборатории, также свидетельствуют о протективных эффектах рекомбинантного эритропоэтина при L-NAME-индуцированной эндотелиальной дисфункции [4], ишемии конечности [3], органов брюшной полости [1] и сетчатки глаза [10].

Вышеизложенное позволяет констатировать рациональность сочетания плеотропных эффектов рекомбинантного эритропоэтина и статинов при эндотоксин-индуцированной патологии сердечно-сосудистой системы.

\section{ЛИТЕРАТУРА}

1. Алехин С.А., Покровский М.В., Иванова Л.В., Назаренко Д.П., Колмыков Д.И., Бусловская Л.К., Колесник И.М., Писарев Д.И Модуляция рекомбинантным эритропоэтином реакции микроциркуляторного русла органов брюшной полости на ишемию/реперфузию // Кубанский научный медицинский вестник. - 2014. № 2(144). - С. 9-11.

2. Гуманова Н.Г., Аршюшкова Е.Б., Мешельская В.А., Кочкаров В.И., Покровская Т.Г., Даниленко Л.М., Корнеев М.М., Покровский М.В., Пашин Е.Н Влияние антиоксидантов Q510 и резвератрола на регуляторную функцию эндотелия у крыс с моделированной артериальной гипертонией // Бюллетень экспериментальной биологии и медицины. - 2007. - Т. 143, № 6. - С. 619-622.

3. Колесник И.М., Покровский М.В., Покровская Т.Г., Гудырев О.С., Даниленко Л.М., Корокин М.В., Алехин С.А., Григоренко А.П., Старосельцева О.А., Должикова И.Н., Братчиков О.И., Молчанова О.В., Ефременкова Д.А., Полянская О.С., Филимонов B.A Фармакологическое прекондиционирование эритропоэтином при ишемии конечности // Биомедицина. - 2011. - Т. 1, № 4. С. 90-92.

4. Корокина Л.В., Колесник И.М., Покровский М.В., Корокин М.В., Белоус А.С., Артюшкова Е.Б., Покровская Т.Г., Гудырев О.С., Королев А.Е., Павлова Л.А., Новиков О.О. Фармакологическая коррекция L-NAME индуцированного дефицита оксида азота рекомбинантным эритропоэтином // Кубанский научный медицинский вестник. 2009. - № 9. - С. 66-69.

5. Локтионова И.Л., Покровский М.В., Рагулина В.А., Титарева Л.В., Денисюк Т.А., Ступакова Е.В., 
Сытник М.В., Сароян К.В., Лосенок С.А. Состояние функции сосудистого эндотелия при инфекционной патологии различной этиологии // Научные ведомости Белгородского государственного университета. Серия: Медицина. Фармация. - 2012. - Т. 17, № 4-1(123). - С. 20-31.

6. Покровский М.В., Артюшкова Е.Б., Покровская Т.Г Способы экспериментального моделирования эндотелиальной дисфункции // Аллергология и иммунология. - 2008. - Т. 9, № 3. - С. 327.

7. Покровский М.В., Покровская Т.Г., Кочкаров В.И. Артюшкова Е.Б. Эндотелиопротекторные эффекты L-аргинина при моделировании дефицита окиси азота // Экспериментальная и клиническая фармакология. - 2008. - № 71 (2). - С. 29-31.

8. Савельев В.С., Яблоков Е.Г., Петухов В.А. Липидный дистресс-синдром в хирургии // Бюл. экспер. биол. - 1999. - Т. 127, № 6. - С. 604-611.

9. Савельев В.С., Петухов В.А., Ан Е.С. Дисфункция эндотелия при липидном дистресс-синдроме и дисметаболических последствиях перитонита // Русский медицинский журнал - 2009. - Т. 17, № 14. - С 1-11.

10. Шабельникова А.С., Кашуба А.С., Пересыпкина А.А., Покровский М.В. Изучение протективных свойств эритропоэтина на модели ишемии-реперфузии сетчатки // Современные наукоемкие технологии. - 2014. - № 10. - С. 76-77.

11. Шабельникова А.С., Кашуба А.С., Пересыпкина А.А., Покровский М.В., Должиков А.А., Бусловская Л.К Протективное действие эритропоэтина при моделировании ишемии-реперфузии сетчатки // Научные ведомости Белгородского государственного университета. Серия: Медицина. Фармация. - 2014. - Т. 26, № 11-1(182). - С. 109-112.

12. Buemi M., Nostro L., Romeo A. From the oxygen to the organ protection: erythropoietin as protagonist in internal medicine // Cardiovasc Hematol Agents Med Chem. - 2006. - Vol. 4, N 4. - P. 299-311.

13. Cai Z., Manalo D.J, Wei G., Rodriguez E.R., FoxTalbot K., Lu J.L., Zweier H., Semenza G.L. Hearts from rodents exposed to intermittent hypoxia or erythropoietin are protected against ischemiareperfusion injury // Circulation. - 2003. Vol. 108. - P. 79-85.

14. Caiola $K$. Use of erythropoietin in heart failure management // Ann. Pharmacother. - 2004. - Vol. 38, N 12. - P. 2145-2149.

15. Ficher J.M. Erythropoietin: Physiology and Pharmacology Update // Exp Biol Med. - 2003. Vol. 228. - P. 1-14.

16. Heeschen C., Aicher A., Lehmann R., Fichtlscherer S., Vasa M., Urbich C. Erythropoietin is a potent physiologic stimulus for endothelial progenitor cell mobilization // Blood. - 2003. - Vol. 102. P. 1340-1346.

17. Parsa C.J., Kim J., Riel R.U., Pascal L.S., Thompson R.B., Petrofski J.A., Matsumoto A., Stamler J.S., Koch W.J. Cardioprotective effects of erythropoietin in the reperfused ischemic heart // J. Biological. 2004. - Vol. 279, N 20. - P. 655-662.

18. Parsa C.J., Matsumoto A., Kim J., Riel R.U., Pascal L.S., Walton G.B., Thompson R.B., Petrofski J.A., Annex B.H., Stamler J.S., Koch W.J. A novel protecttive effects of erythropoietin in the infarcted heart // J. Clin. Investig. - 2003. - Vol. 112. - P. 999-1007.

19. Taoufik E., Petit E., Divoux D., Tseveleki V., Mengozzi M., Roberts M.L., Valable S., Ghezzi P., Quackenbush J., Brines M., Cerami A., Probert L. The receptor I sensitizes neurons to erythropoietin -and VEGF-mediated neuroprotection after ischemic and excitotoxic injury // PNAS. - 2008. - Vol. 105, N 16. - P. 6185-6190.

20. van der Meer P., Lipsic E., Henning R.H., Boddeus K., van der Velden J., Voors A.A., van Veldhuisen D.J., van Gilst W.H., Schoemaker R.G. Erythropoietin induces neovascularization and improves cardiac function in rats with heart failure after myocardial infarction // J. Am. Coll. Cardiol. - 2005. - Vol. 46. P. 125-133. 